\title{
New interdisciplinary research on Neolithic-Eneolithic sites in the Low Volga River region
}

\author{
Marianna A. Kulkova ', Alexandr A. Vybornov ${ }^{2}$, Aleksandr Yudin ${ }^{3}$, Nataliya Doga $^{2}$, \\ and Aleksandr Popov ${ }^{2}$ \\ 1 Herzen State University, Sankt Petesburg, RU \\ kulkova@mail.ru \\ 2 Samara State University of Social Sciences and Education, Samara, RU \\ 3 Research and Production Center on the Historical and Cultural Heritage of the Saratov Region, Saratov, RU
}

\begin{abstract}
The Neolithic and Eneolithic sites in the Low Volga River region have been poorly investigated in comparison with other territories due to a small number of excavated sites. On the Algay site and the Oroshaemoe I settlement there is evidence of the earliest appearance of Neolithic pottery and the first sign of domestication in the Eneolithic period within the Volgo-Ural territory. Archaeological, lithological, grain-size analyses, mineralogical-geochemical methods and radiocarbon dating of cultural deposits have been applied to reconstruct the palaeoenvironment in the Holocene in this area. The results show that the landscape-climatic conditions in the steppe area of the Lower Volga basin strongly affected the development and adaptation of ancient societies.
\end{abstract}

KEY WORDS - Neolithic; domestication; Eneolithic; Low Volga River region; geochemical indication; Holocene climate; steppe

\section{Nove interdisciplinarne raziskave neolitskih in eneolitskih najdišč na območju Spodnje Volge}

\begin{abstract}
IZVLEČEK - Neolitska in eneolitska najdišča na območju Spodnje Volge so bila v preteklosti zaradi maloštevilnih izkopavanj slabše raziskana v primerjavi z drugimi regijami. Na najdiščih Algay in Oroshaemoe I smo odkrili najstarejši pojav neolitske lončenine in prve znake domestikacije v obdobju eneolitika na območju Volge in Urala. Za rekonstruiranje holocenskega paleookolja na tem območju smo uporabili arheološke, litološke metode, analize velikosti zrn, mineraloško-geokemične metode in radiokarbonsko datiranje kulturnih ostalin. Rezultati kažejo, da so okoljski in klimatski pogoji na območju stepe ob Spodnji Volgi močno vplivali na razvoj in prilagoditve preteklih družb.
\end{abstract}

KLJUČNE BESEDE - neolitik; domestikacija; eneolitik; območje Spodnje Volge; geokemične indikacije; klima v holocenu; stepa

\section{Introduction}

The Low Volga River region borders Middle Asia and Caucuses, where the ceramic manufacture and producing economy appeared very early on. The steppe Povolzhie connects the steppe-forest and forest zones as far as the Don River region and Ural. Therefore the study of archaeological sites on the territory of the Low Volga River region is important. Besides, the Neolithic and Eneolithic sites in the Povolzhie region have been poorly investigated in comparison with other territories (Yudin 2004; 2012). As a result of this the distinctive features of human development in this territory are still under discussion. There is only some information available about palaeogeography during the Holocene in this region (Spiridonova, Aleshinskaya 1999). In this context an interdisciplinary approach to the study of these 
sites is needed. Some processes in the development of ancient societies were connected with palaeoclimatic changes during the Holocene (Budja 2015; Kulkova 2007), and these changes were significant in the steppe zone.

The Algay site and the Oroshaemoe settlement located in the Alexandrovsky district of Saratovskaya oblast', on the right bank of Bolshoy Uzen' River are currently being excavated (Fig. 1), and from 2014-2018 the multidisciplinary investigations were conducted on these sites (Vybornov et al. 2015a; 2015b; 2016a; 2016b; 2017a; $2017 b$; 2018a; 2018b; 2018c). The Oroshaemoe site has a special emphasis in the whole archaeological context, as here well-defined layers of archaeological and lithological stratigraphic succession

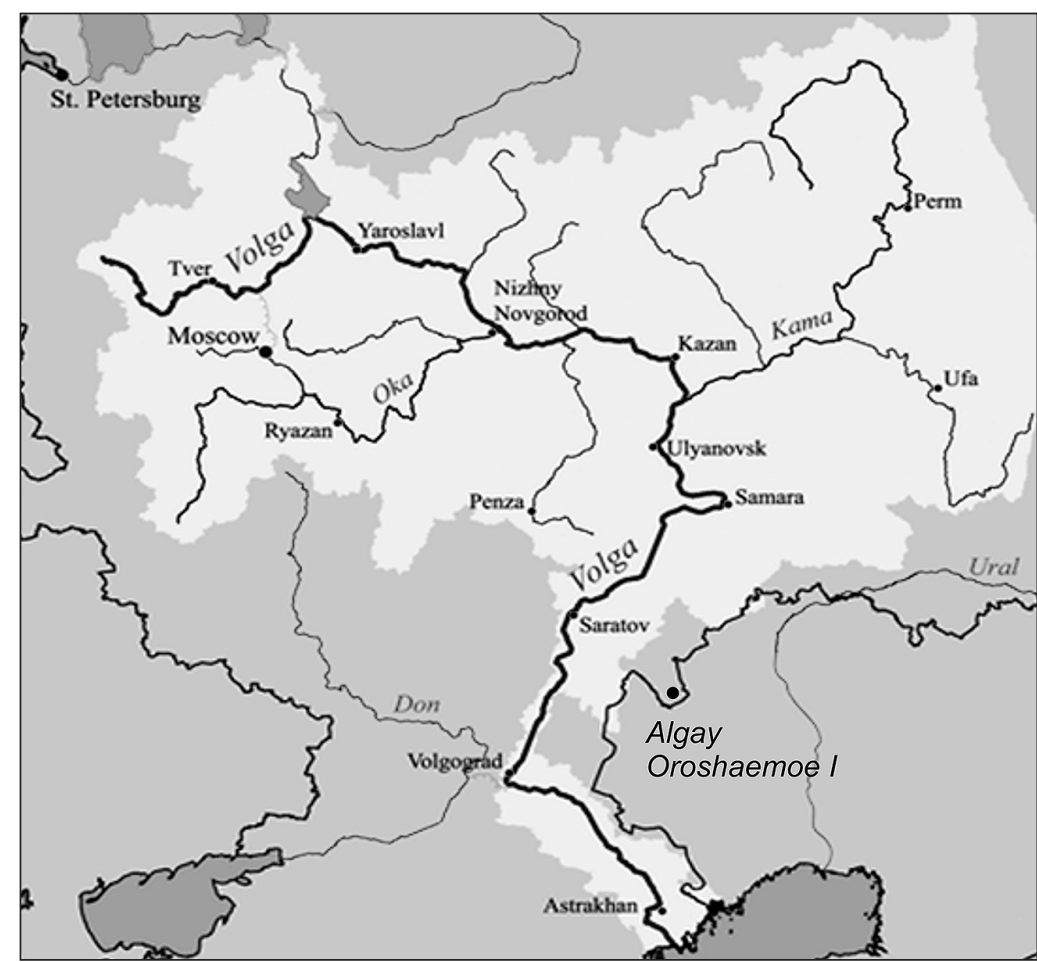

Fig. 1 The map of Algay and Oroshaemoe I sites location. were documented. The cultural layers with Neolithic and Eneolithic finds are divided by sterile horizons (Fig. 2).

On the Algay site and the Oroshaemoe I settlement there is evidence of the earliest appearance of Neolithic pottery and the first sign of domestication in the Eneolithic period on the Volgo-Ural territory ( $V y$ bornov et al. 2016a). It is thus interesting to consider the climatic conditions in these periods.

\section{Materials and methods}

On both sites complex, detailed investigations of lithological and cultural deposits from the cross-sections were carried out. Archaeological, lithological, grain-size analyses, mineralogical-geochemical methods and radiocarbon dating (Tab. 1) were applied for deposit investigations. The lithology of deposits is presented in Figures 3 and 4. Samples for analysis were taken from each $5 \mathrm{~cm}$ cross-section.

The chemical composition of loess loam deposits from cross-sections on the Algay and Oroshaemoe I sites was determined by XRF-WD analysis using the Spectroscan Max equipment. Probing was carried out with a fine-grained fraction of $<0.25 \mathrm{~mm}$ which was ground in an agate mortar into powder state. The tablets for XRF analysis were pressed by means of a hydraulic press using boric acid.
The data on the chemical composition (Tabs. 2 and 4) was calculated by means of the principle component method for determination of landscape-climatic factors that influenced the sedimentation. The key concept of factor analysis is that multiple observed variables have similar patterns of responses, because they are all associated with a latent variable. The number of principal components was determined according to how complex our model will be. The factor corresponding to the largest eigenvalue (7.143237 and 7.833615 for Algay and Oroshaemoe, respectively) accounts for approx. 28.57\% and 31.33\% (Tabs. 3 and 5) of the total variance. The second factor corresponding to the second eigenvalue (4.909768 and 5.180147) accounts for approx. 19.64\% and $20.72 \%$ of the total variance, and so on. When analysing correlation matrices, the sum of the eigenvalues is equal to the number of (active) variables from which the factors were extracted (computed).

We used two main factors of the four that were calculated for determination of sedimentation characteristics for both sites:

- FI ( $\left.\mathrm{CaO}, \mathrm{Sr} / \mathrm{Al}_{2} \mathrm{O}_{3}, \mathrm{SiO}_{2}, \mathrm{MnO}, \mathrm{Fe}_{2} \mathrm{O}_{3}\right)$ shows the antagonism between elements of the carbonate group $(\mathrm{CaO}, \mathrm{Sr})$ and the group of aluminosilicate minerals (clay minerals, quartz) and iron, manganese oxides $\left(\mathrm{Al}_{2} \mathrm{O}_{3}, \mathrm{SiO}_{2}, \mathrm{MnO}, \mathrm{Fe}_{2} \mathrm{O}_{3}\right)$. The positive factor loading corresponds to carbonate precipitation that occurred 
in the period of arid conditions, while the clay minerals and iron-manganese oxides with negative loading are formed in humid climatic conditions (Kulkova 2012). The first factor characterizes the change in relative precipitation. The positive loading of this factor describes the dry climatic conditions and the negative loading indicates wet conditions (Figs. 34). This interpretation is confirmed by other geochemical indicators connected with the relative humidity, like the Chemical Index Alteration (CIA $=\mathrm{Al}_{2} \mathrm{O}_{3}$ / $\left(\mathrm{Al}_{2} \mathrm{O}_{3}+\mathrm{CaO}+\mathrm{Na}_{2} \mathrm{O}+\mathrm{K}_{2} \mathrm{O}\right)$ (Nesbitt, Young 1982) and the $\mathrm{CaO} / \mathrm{MgO}$ ratio. The index of CIA shows the alteration of aluminosilicate minerals as a result of weathering. The $\mathrm{CaO} / \mathrm{MgO}$ ratio indicates increasing of $\mathrm{CaO}$ vs $\mathrm{MgO}$ in the carbonate component in the periods of prevailing dry conditions.

- FII $\left(\mathrm{P}_{2} \mathrm{O}_{5}, \mathrm{Zn}, \mathrm{MgO} / \mathrm{TiO}_{2}\right.$, $\left.\mathrm{La}, \mathrm{Zr}\right)$ shows the antagonism between elements of biogenic processes $\left(\mathrm{P}_{2} \mathrm{O}_{5}\right.$, $\mathrm{Zn}, \mathrm{MgO})$ and heavy, accessory minerals $\left(\mathrm{TiO}_{2}, \mathrm{La}\right.$, $\mathrm{Zr}$ ). This factor is connected with the relative temperature changes. The biogenic complexes are formed in the loam loess deposits together with organics during warm periods, and the accumulation of heavy minerals connects with a coarse grain sediment fraction accumulating during cold conditions. So, the positive loading of the second factor indicates the warm conditions and the negative loading is the cold conditions. Besides, the relative temperature variations are marked by the distribution of zirconium $(\mathrm{Zr})$ in the deposits of cross-sections and the distribution of titanium modules $\left(\mathrm{TiO}_{2} / \mathrm{Al}_{2} \mathrm{O}_{3}\right)$ (Yudovich, Kertis 2000). The high titanium content in this case indicates the accumulation of heavy titanium minerals in the psammitic fraction, while the increasing alumina component is characteristic of the pelitic fraction. The alumina enrichment of the pelitic fraction as a rule is formed in the conditions of intense chemical weathering with a warm and humid climate.

For assessment of an ancient anthropogenic impact the indicator of $\mathrm{P}_{2} \mathrm{O}_{5}$ antr $=\mathrm{P}_{2} \mathrm{O}_{5} /\left(\mathrm{P}_{2} \mathrm{O}_{5}+\mathrm{Na}_{2} \mathrm{O}\right)$ (Kulkova 2012) was used. Increases in this indicator are correlated with the cultural horizons and remains of bones and ceramics (Figs. 3-4). It is worth noting that geochemical markers allow us to correlate climatic episodes with anthropogenic activity very pre-

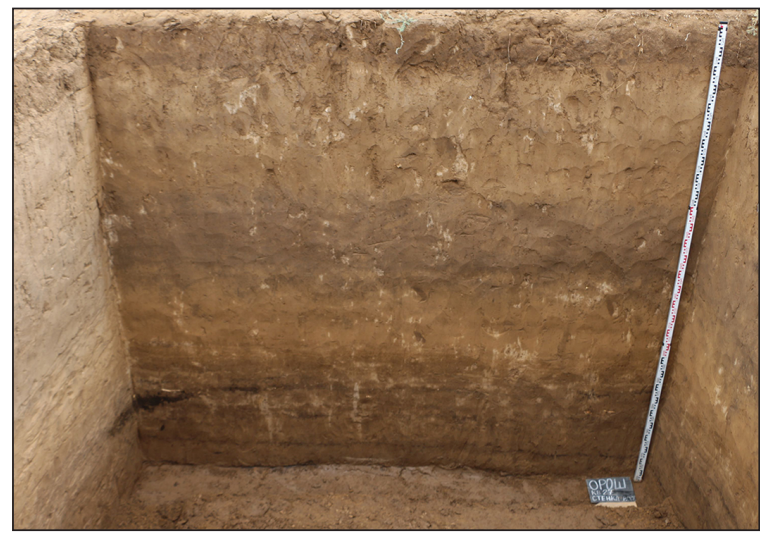

Fig. 2. The cross-section with cultural layers (dark colour) at the Oroshaemoe I settlement.

cisely. This is important for reconstruction of the environment and human migration.

The radiocarbon dates were obtained on different organic materials from various cultural layers. The results are presented in the Table 1. Chronological phases for the different cultural traditions on the Algay site were calculated by means of Bayesian statistics with the help of OxCal 4.2 (Bronk Ramsey 2009) (Fig. 5).

\section{Results}

\section{The archaeological characteristics of the Algay and Oroshaemoe I sites}

\section{The Oroshaemoe I site}

The upper cultural layer on the Oroshaemoe I site comprises ceramics and stone tools, which have ana-

\begin{tabular}{|lcccc}
\hline Site & $\begin{array}{c}\text { 14C date } \\
\text { (BP) }\end{array}$ & Lab index & $\begin{array}{c}\text { Calendar age 20 } \\
\text { (cal BC) }\end{array}$ & Material \\
\hline Algay & $5875 \pm 60$ & SPb_1968 & $4571-4558$ & animal bone \\
\hline Algay & $6245 \pm 32$ & AAR 21891 & $5309-5076$ & food crusts \\
\hline Algay & $6284 \pm 100$ & SPb-2038 & $5472-5018$ & animal bone \\
\hline Algay & $6318 \pm 33$ & AAR-21892 & $5361-5221$ & animal bone \\
\hline Algay & $6490 \pm 40$ & Poz-76004 & $5527-5367$ & charcoal \\
\hline Algay & $6479 \pm 70$ & SPb_1477 & $5560-5316$ & animal bone \\
\hline Algay & $6360 \pm 250$ & SPb_1411 & $5742-4723$ & charcoal \\
\hline Algay & $6605 \pm 32$ & AAR-21893 & $5617-5487$ & charcoal \\
\hline Algay & $6577 \pm 80$ & SPb_1478 & $5641-5374$ & animal bone \\
\hline Algay & $6654 \pm 80$ & SPb_1509 & $5708-5479$ & animal bone \\
\hline Algay & $6820 \pm 80$ & SPb_1510 & $5889-5614$ & animal bone \\
\hline Algay & $6800 \pm 40$ & Poz-65198 & $5741-5631$ & food crusts \\
\hline Algay & $7284 \pm 80$ & SPb_2144 & $6271-6008$ & humic acids \\
\hline Oroshaemoe I & $5806 \pm 26$ & UGAMS-23059 & $4724-4557$ & animal bone \\
\hline Oroshaemoe I & $5934 \pm 100$ & SPb_2091 & $5060-4547$ & animal bone \\
\hline Oroshaemoe I & $7010 \pm 110$ & SPb_2143 & $6072-5674$ & charcoal \\
\hline Oroshaemoe I & $7245 \pm 60$ & SPb_2141 & $6227-6015$ & charcoal \\
\hline
\end{tabular}

Tab. 1. Radiocarbon dates on organics from the cultural layers of the Algay and Oroshaemoe I sites. 


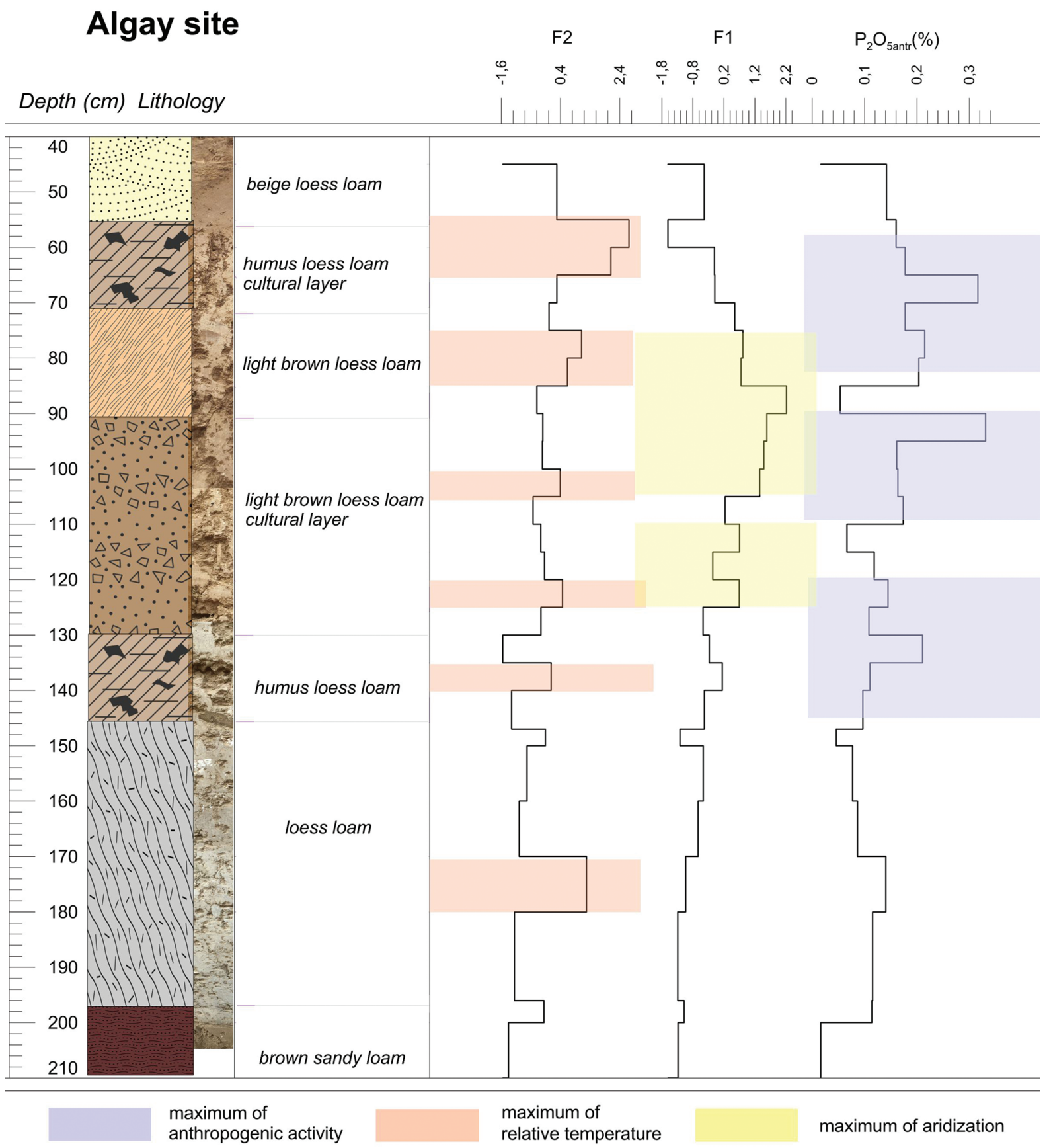

Fig. 3 Lithology and stratigraphy of a cross-section at the Algay site with geochemical indicators of the palaeoenvironment.

logies with materials of the Khvalynskaya Eneolithic culture (Vybornov 2010; Vybornov et al. 2015b; Yudin 2012). This is supported by the radiocarbon dates of $c .4725 \mathrm{cal} \mathrm{BC}$ obtained on the kulan (Equus hemionus; Asian wild ass) bones from this layer. The development of Khvalynskaya culture corresponds to this time. This layer and the next bottom cultural layer are separated by a sterile horizon without any finds.

The next cultural horizon belongs to the Cis-Caspian culture (Yudin 2012; Vybornov et al. 2015a; 2015b).
Ceramics were made of fat silt clay tempered with crushed shells of freshwater molluscs. Vessels have flat bottoms and the upper part of the corollas has a thick edge. The decoration consists of a combination of comb-stamp prints with incised lines (Fig. 6). Stone tools were made of quartzite. The massive stone blanks were produced by the technique of reinforced extraction. Stone tools are presented by different types of scrapers, knifes, perforators and arrow points in the shape of fish (Fig. 7). Taking into account the radiocarbon age of the cultural layer, the forming of this horizon lasted about 200 years. 
The radiocarbon dates of the artefacts from this layer lie in the interval of $c$. 50004700 cal BC (Tab. 1). The bones of domestic sheep and goat were also found in this horizon, while below this layer a sterile horizon without finds was registered.

One more cultural horizon was recovered below the sterile layer. This cultural layer comprises artefacts similar to those of the Orlovskaya Neolithic culture (Yudin 2004). The clay wares have the same shape as the pottery of the Cis-Caspian culture. As a rule they are flat-bottom vessels with thickening on the inner part of the corolla which has a decoration. The ornamental compositions are presented by horizontal and inclined incised rows of lines and pins, as well as horizontal zigzags (Fig. 8). The stone tools were made of grey and black flint. The tools were produced from plates and flakes. In the stone tool collection there are scrapers of different types, points and geometric microliths (Fig. 8). The time of the appearance of the carriers of these cultural traditions is $c$. 6200-5900 cal BC (Tab. 1). This is the first stage of the Orlovskaya culture and the appearance of pottery in this region.

\begin{tabular}{|lcccc|}
\hline & Factor-1 & Factor-2 & Factor-3 & Factor-4 \\
\hline $\mathrm{TiO}{ }_{2}$ & -0.525397 & -0.374604 & 0.638549 & 0.012623 \\
\hline $\mathrm{V}$ & 0.143179 & 0.103815 & 0.606115 & -0.507017 \\
\hline $\mathrm{Cr}$ & -0.675516 & -0.304983 & -0.174911 & -0.206581 \\
\hline $\mathrm{MnO}$ & -0.792146 & -0.216703 & 0.180964 & -0.104813 \\
\hline $\mathrm{Fetot}$ & -0.713308 & 0.253115 & 0.545018 & -0.014104 \\
\hline $\mathrm{Co}$ & 0.090292 & -0.539679 & 0.511056 & 0.312753 \\
\hline $\mathrm{Ni}$ & -0.502823 & 0.325697 & 0.692857 & 0.010736 \\
\hline $\mathrm{Cu}$ & -0.184474 & -0.300061 & 0.791513 & -0.315741 \\
\hline $\mathrm{Zn}$ & -0.097698 & 0.801005 & 0.361113 & 0.221405 \\
\hline $\mathrm{Sr}$ & 0.646855 & -0.416596 & 0.365335 & -0.031197 \\
\hline $\mathrm{Pb}$ & -0.234403 & 0.650516 & -0.177654 & -0.464782 \\
\hline $\mathrm{CaO}$ & 0.832749 & -0.113885 & 0.214682 & -0.079583 \\
\hline $\mathrm{Al}{ }_{2} \mathrm{O}_{3}$ & -0.826869 & 0.370054 & -0.021148 & -0.017131 \\
\hline $\mathrm{SiO}{ }_{2}$ & -0.815570 & -0.166060 & -0.474301 & -0.027936 \\
\hline $\mathrm{P}_{2} \mathrm{O}_{5}$ & 0.429003 & 0.782884 & 0.137864 & 0.210849 \\
\hline $\mathrm{K} \mathrm{O}_{2} \mathrm{O}$ & -0.492875 & 0.595141 & -0.096002 & 0.439756 \\
\hline $\mathrm{MgO}$ & 0.042608 & 0.686980 & 0.484446 & 0.147126 \\
\hline $\mathrm{Rb}$ & -0.714046 & 0.238823 & -0.010265 & 0.343295 \\
\hline $\mathrm{Ba}$ & -0.462564 & 0.227406 & -0.066073 & -0.371593 \\
\hline $\mathrm{La}$ & -0.434701 & -0.489385 & -0.207699 & 0.198198 \\
\hline $\mathrm{Y}$ & -0.696520 & -0.231848 & 0.140597 & 0.029511 \\
\hline $\mathrm{Zr}$ & -0.471691 & -0.228049 & -0.302956 & 0.105400 \\
\hline $\mathrm{Nb}$ & 0.450337 & 0.265520 & 0.085704 & 0.559210 \\
\hline $\mathrm{Na} 2 \mathrm{O}$ & 0.419005 & 0.413458 & -0.182563 & -0.469158 \\
\hline $\mathrm{As}$ & 0.078930 & -0.718983 & 0.288837 & 0.280350 \\
\hline $\mathrm{Expl} . \mathrm{Var}$ & 7.143237 & 4.909768 & 3.616330 & 1.960236 \\
\hline $\mathrm{Prp} \cdot \mathrm{Totl}$ & 0.285729 & 0.196391 & 0.144653 & 0.078409 \\
\hline
\end{tabular}

Tab. 2. Algay site. Factor loadings (unrotated) extraction: principal components.

\section{The Algay site}

The archaeological materials that have been found on the Algay site give additional information with regard to the Oroshaemoe I site about the development of people at this place. In the lower cultural layer on the Algay site, straight wall wares with flat bottoms were found. They are ornamented by pins in a triangular manner with incised lines and notches. The compositions are presented by horizontal rows and zigzags (Fig. 9). The flint tools include plates and flakes. Scrapers of different types, points, geometric microliths and segments with geluanian retouching are most common (Fig. 9). One of main types of retouching is the geluanian retouching. This type includes the sharpening of microliths and segments from two sides. The chronological period of

\begin{tabular}{|lcccc|}
\hline Eigenvalue & $\begin{array}{c}\text { \% Total- } \\
\text { variance }\end{array}$ & $\begin{array}{c}\text { Cumulative- } \\
\text { Eigenvalue }\end{array}$ & $\begin{array}{c}\text { Cumulative } \\
\%\end{array}$ \\
\hline 1 & 7.143237 & 28.57295 & 7.14324 & 28.57295 \\
\hline 2 & 4.909768 & 19.63907 & 12.05300 & 48.21202 \\
\hline 3 & 3.616330 & 14.46532 & 15.66934 & 62.67734 \\
\hline 4 & 1.960236 & 7.84095 & 17.62957 & 70.51829 \\
\hline
\end{tabular}

Tab. 3. Algay site. Eigenvalues extraction: principal components.

this cultural era is from 5900 to 5700 cal BC (Vybornov et al. 2017a; 2017b; Yudin et al. 2016). Thereby this is the later stage of the Orlovskaya cultural development in comparison with the lower layer on the Oroshaemoe I site.

In the upper of this horizon there is a thin sterile layer and the next cultural layer also contains artefacts of the Orlovskaya culture, although the finds have some differences from the Orlovskaya bottom layer. Especially ceramics vessels show significant differences. On the inner part of the corolla there is a thickening with oval-shaped impressed decoration. This complex decorative composition on the ware walls was first observed in the Orlovskaya cultural tradition (Fig. 10). The stone industry forms from this layer have substantially changed, and microliths with a trapezium shape and dorsal retouching were found (Fig. 10). Several radiocarbon dates were obtained for this cultural layer, and they are in the interval from 5500 to 5300 cal BC (Tab. 1). A thin sterile interlayer separates the cultural layer of later stage of the Orlovskaya culture from the next Cis-Caspian culture. Ceramics and tools made of quartzite were discovered in the Cis-Caspian culture layer dated to 4800-4700 cal BC (Tab. 1). 
The reconstruction of palaeoclimatic conditions during the Holocene

\section{The Oroshaemoe I site}

At the depth of $280-265 \mathrm{~cm}$ loess loam with carbonate inclusions was discovered (Fig. 4). The sedimentation at the depth of $270-260 \mathrm{~cm}$ was during the ending of a cold and dry event and the transition to moderately humid and warm conditions. In Figure 4 there is a trend from negative to positive for F2 and the transition from positive to negative for F1. These climatic conditions occurred about $c$.
$6000 \mathrm{cal} \mathrm{BC}$. The first evidence of carriers of the Orlovskaya culture are around this time.

At the depth of $265-243 \mathrm{~cm}$ grey-beige loess loam is recorded. The radiocarbon age of this horizon is $c$. 5900-5600 cal BC. High anthropogenic activity was registered in this layer. The occupation of the site by carriers of the Orlovskaya cultural traditions begins exactly in this period.

Loess loam with a beige colour with carbonate inclusions is deposited at a depth of $243-150 \mathrm{~cm}$. In this

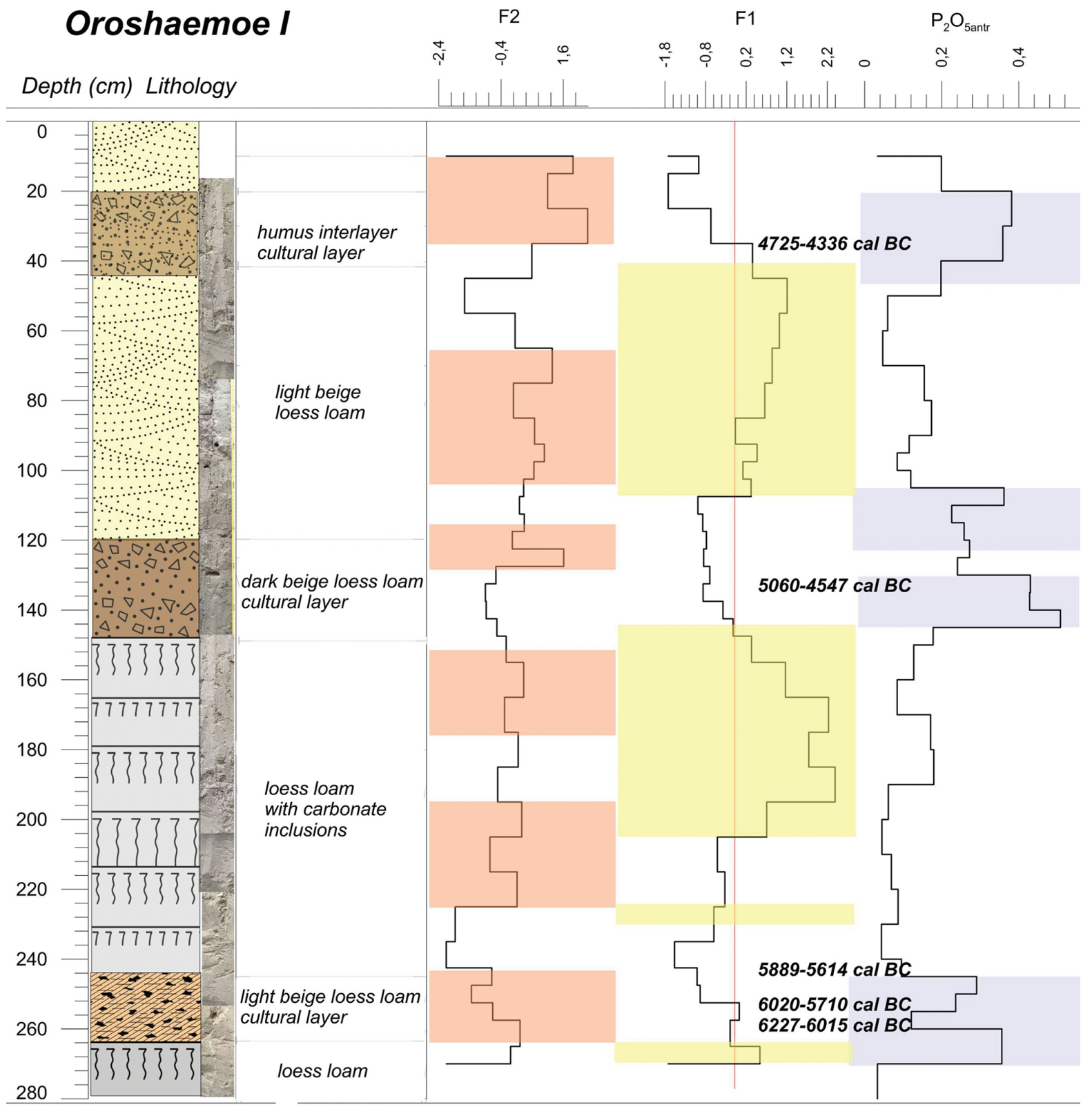


horizon low anthropogenic impact was registered. The maximum period of aridization and warm climatic conditions are marked on the basis of the geochemical indicators in these deposits. Especially strong arid conditions with carbonate formation are registered at the depth of $200-150 \mathrm{~cm}$ on the basis of the F1 positive results. This episode coincides to $c .5050 \mathrm{cal} \mathrm{BC}$.

The dark-beige loess loam is recorded at the depth of $150-120 \mathrm{~cm}$. The climatic conditions at the beginning of this sedimentation period were cold and humid, and both $\mathrm{F} 1$ and F2 are negative. At the end of this period of sedimentation there is a transition to the humid and warm conditions. This is registered on the basis of the positive value of F2. The anthropogenic activity is high. The artefacts of the Cis-Caspian culture are dated to $c$. 5000-4700 cal BC. The climatic Holocene maximum probably correlates with this period.

The next event of maximum aridization and high temperatures was recorded in the deposits of the light-beige loess loam at the depth of $100-70 \mathrm{~cm}$. Again, the high positive values of F1 and F2 show this. This was shortterm episode with rapid sedimentation, and the level of anthropogenic activity was low.

The transition from a dry to humid climatic period is marked in the deposits at the depth of $65-40 \mathrm{~cm}$. The $\mathrm{F} 1$ values show a trend from positive to negative.

The upper layer $(45-20 \mathrm{~cm})$ is presented by the humus interlayer in the deposits of loess loam which were sedimented during warm and humid conditions. The F1 values are negative while those for F2 are positive. The anthropogenic activity rises again. The radiocarbon age of organic artefacts from this layer is $4700-4336 \mathrm{cal} \mathrm{BC}$. This was the period of the development of the Khvalynskaya Eneolithic culture.

\section{The Algay site}

In the bottom part of the cross-section $(210-196 \mathrm{~cm})$ on the Algay site (Fig. 3) there is brown sandy loam. The climatic conditions were at this time moderately wet. The values of F1 and F2 are close to zero.

The formation of grey loess loam on the depth of $196-147 \mathrm{~cm}$ was during a moderately humid and warm climate with a short-term episode of cooling.

\begin{tabular}{|c|c|c|c|c|}
\hline & Factor-1 & Factor-2 & Factor-3 & Factor-4 \\
\hline $\mathrm{TiO}_{2}$ & -0.778071 & -0.361129 & -0.046335 & -0.048206 \\
\hline$\sqrt{ }$ & -0.413724 & -0.233325 & 0.514376 & 0.104239 \\
\hline $\mathrm{Cr}$ & -0.375471 & -0.393625 & 0.157189 & 0.188755 \\
\hline $\mathrm{MnO}$ & -0.928402 & -0.022105 & -0.150060 & 0.141842 \\
\hline Fetot & -0.911664 & -0.360517 & -0.028562 & -0.110745 \\
\hline Co & -0.238642 & -0.718360 & -0.251143 & 0.372272 \\
\hline $\mathrm{Ni}$ & -0.789704 & 0.018054 & 0.142277 & -0.461662 \\
\hline $\mathrm{Cu}$ & -0.402804 & -0.755680 & -0.302772 & 0.081161 \\
\hline $\mathrm{Zn}$ & -0.860105 & 0.350439 & -0.110814 & -0.099737 \\
\hline Sr & 0.289314 & -0.746120 & -0.332121 & -0.312762 \\
\hline $\mathrm{Pb}$ & -0.102168 & 0.045123 & -0.848618 & -0.219134 \\
\hline $\mathrm{CaO}$ & 0.720024 & -0.320048 & 0.156392 & -0.436712 \\
\hline $\mathrm{Al}_{2} \mathrm{O}_{3}$ & -0.791232 & 0.499724 & 0.011110 & -0.269376 \\
\hline $\mathrm{SiO}_{2}$ & -0.206384 & 0.867991 & -0.036818 & 0.084382 \\
\hline $\mathrm{P}_{2} \mathrm{O}_{5}$ & -0.465666 & 0.755840 & -0.048370 & -0.039471 \\
\hline $\mathrm{K}_{2} \mathrm{O}$ & -0.624663 & 0.654979 & 0.141454 & 0.221338 \\
\hline $\mathrm{MgO}$ & -0.187295 & -0.076565 & -0.223522 & -0.843921 \\
\hline $\mathrm{Rb}$ & -0.857427 & -0.348934 & -0.156778 & 0.004863 \\
\hline $\mathrm{Ba}$ & -0.454333 & -0.279516 & 0.534705 & 0.042600 \\
\hline La & -0.346207 & -0.292131 & 0.469610 & -0.048956 \\
\hline$Y$ & -0.801067 & -0.202919 & -0.102270 & -0.002583 \\
\hline $\mathrm{Zr}$ & 0.018071 & 0.502598 & -0.242704 & 0.337912 \\
\hline $\mathrm{Nb}$ & 0.001422 & -0.079008 & -0.722107 & 0.192327 \\
\hline $\mathrm{Na}_{2} \mathrm{O}$ & 0.116133 & 0.305007 & 0.232280 & -0.639645 \\
\hline As & -0.008519 & -0.388506 & 0.572406 & 0.066714 \\
\hline Expl.Var & 7.833615 & 5.180147 & 2.934171 & 2.197460 \\
\hline Prp.Totl & 0.313345 & 0.207206 & 0.117367 & 0.087898 \\
\hline
\end{tabular}

Tab. 4. Oroshaemoe site. Factor loadings (unrotated) extracion: principal components.

The warm episode is registered at the depth of 180$170 \mathrm{~cm}$ on the basis of increasing $\mathrm{F} 2$ values. The anthropogenic loading is low.

At the depth of $147-130 \mathrm{~cm}$ humified loess loam with artefacts from the Orlovskaya culture was deposited. On the basis of geochemistry this layer is characterized by high anthropogenic loading. The climatic conditions are recorded as humid and warm (negative F1 and positive F2). The radiocarbon dates for this layer lie in the interval of 5800-5650 cal BC. In Figure 3 the Bayesian model of the distribution of the radiocarbon dates for this site is presented. It should be noted that several groupings of dates are divided by lacunae. The first lacuna falls on the radiocarbon 'plateau' of 5656-5566 cal BC. This episode correlates with the period of temperature de-

\begin{tabular}{|ccccc|}
\hline Eigenvalue & $\begin{array}{r}\text { \% Total- } \\
\text { variance }\end{array}$ & $\begin{array}{c}\text { Cumulative- } \\
\text { Eigenvalue }\end{array}$ & $\begin{array}{c}\text { Cumulative } \\
\%\end{array}$ \\
\hline 1 & 7.833615 & 31.33446 & 7.83362 & 31.33446 \\
\hline 2 & 5.180147 & 20.72059 & 13.01376 & 52.05505 \\
\hline 3 & 2.934171 & 11.73669 & 15.94793 & 63.79173 \\
\hline 4 & 2.197460 & 8.78984 & 18.14539 & 72.58157 \\
\hline
\end{tabular}

Tab. 5. Oroshaemoe site. Eigenvalues extraction: principal components. 


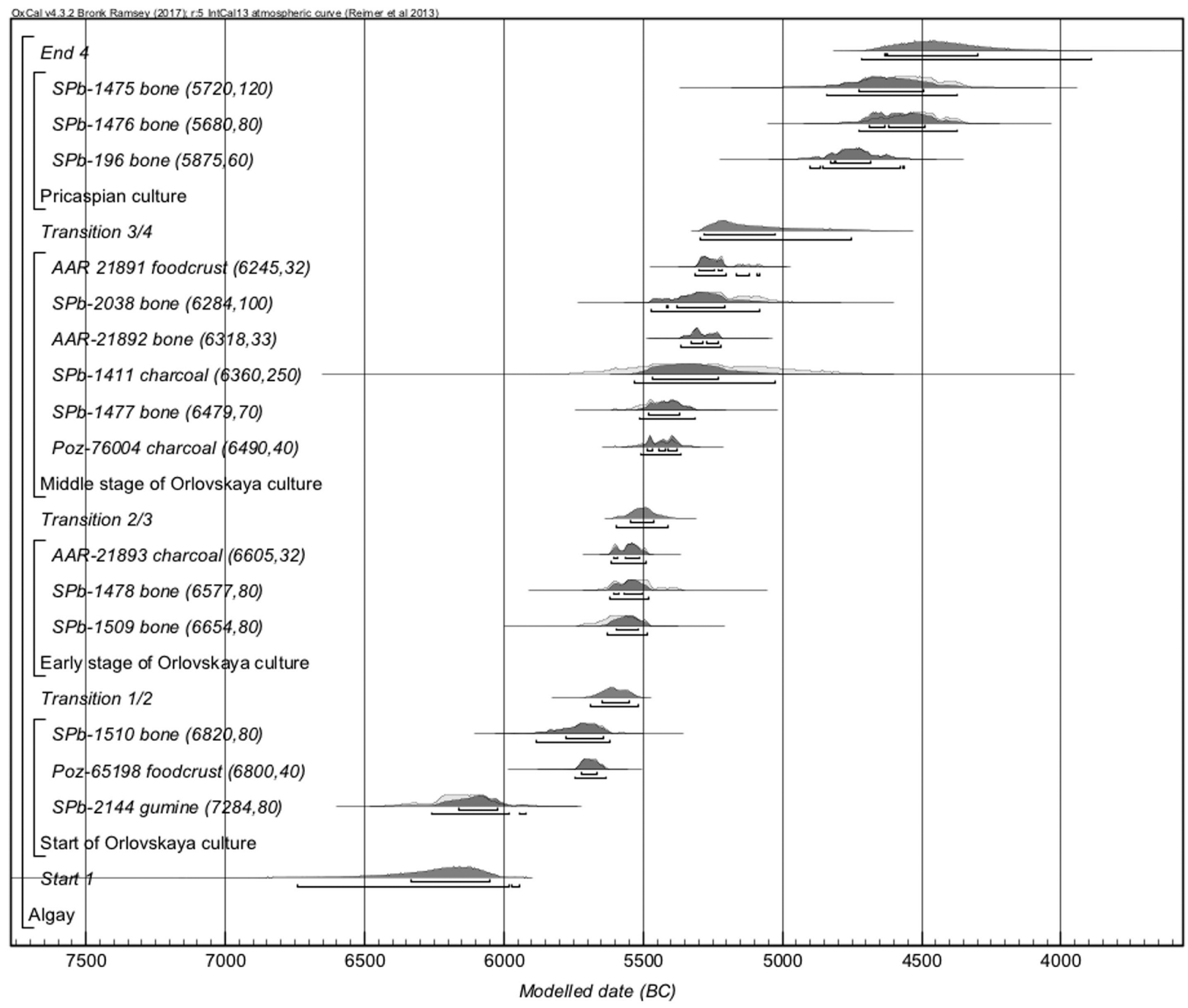

Fig. 5. Chronological phases for the different cultural traditions at the Algay site.

creasing and aridization that is registered by the geochemical indicators in deposits at the depth of 127$132 \mathrm{~cm}$. These conditions are supported by the negative values of $\mathrm{F} 1$ and $\mathrm{F} 2$.

At the depth of $130-90 \mathrm{~cm}$ light brown loess loam was sedimented. The climatic conditions in this period were warm with a trend to aridization. There are high, positive values of F1. High levels of higher anthropogenic activity are revealed at the depth of 130$120 \mathrm{~cm}$. The radiocarbon dates on artefacts from this layer are from 5600 to $5470 \mathrm{cal} \mathrm{BC}$.

Decreasing anthropogenic activity was registered at the depth of $120-113 \mathrm{~cm}$. This period corresponds with cooling and dry climatic conditions according to the negative values of $\mathrm{F} 2$ and high positive values of F1. The radiocarbon 'plateau' of 5470-5400 cal BC correlates to the climatic deterioration.

The next peak of anthropogenic activity is recorded at the depth of $110-90 \mathrm{~cm}$. This coincides with the cultural layer dated to 5350-5120 cal BC. Increasing temperature and humidity occurred in the period of sedimentation at the depth of $100-105 \mathrm{~cm}$. This episode is marked by positive values of $\mathrm{F} 2$ and a transition from negative to positive values of F1. The deposits at the depth of $100-90 \mathrm{~cm}$ were formed in moderately cold conditions with increasing aridity (high positive values of F1) during 5120-5050 cal BC. This interval also falls on the radiocarbon 'plateau'.

The maximum of aridization and high temperatures occurred according to geochemical data in the period of light beige loam forming at the depth of 85$75 \mathrm{~cm}$. This is marked by high positive values of both F1 and F2. Low anthropogenic activity was revealed in this layer, and this episode can be dated to around 5050-4900 cal BC.

The next period of high anthropogenic activity concerns 4900-4366 cal BC, and this is recorded in the deposits at the depth of $80-55 \mathrm{~cm}$. This stage is characterized by a humid and cold climate (negative 
values for both $\mathrm{F} 1$ and $\mathrm{F} 2$ ), but at the end there is marked the transition to humid and warm conditions (positive values of $\mathrm{F} 2$ ).

\section{Discussion}

The local features of the Oroshaeomoe I site located on the riverbank were more favourable for certain types of household activities during humid periods. This place was protected from winds and therefore the local humidity was higher than on the Algay site. At Algay, situated in an elevated place, a low rate of sedimentation was recorded in the periods of aridization. The intensive rate of weathering in this area resulted in the lower accumulation of deposits. Conversely, at the Oroshaemoe I site the thickness of deposits is greater, especially for sedimentation during arid periods.

According to Nataliya S. Bolikhovskaya (2011) the Early stage of the Atlantic period about $c$. 7000-6600 $\mathrm{BC}$ in the Low
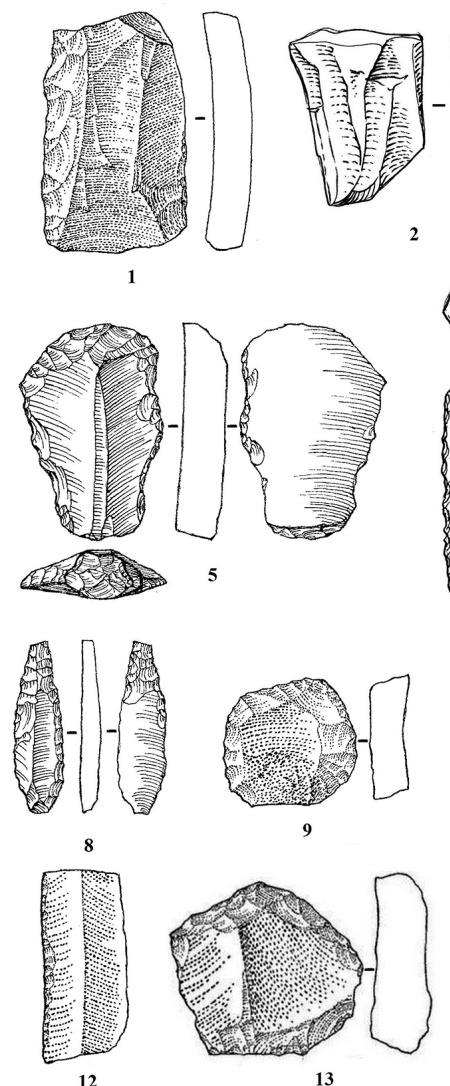

2
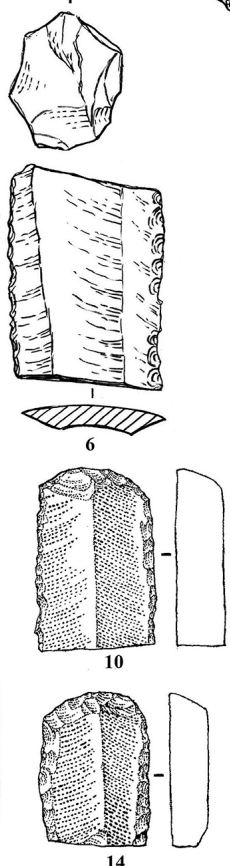
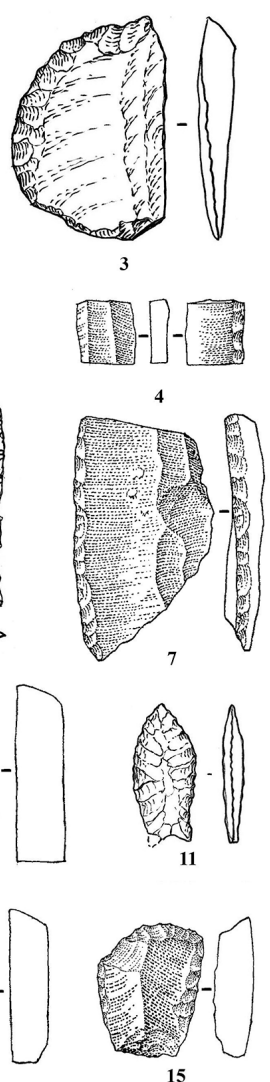

4
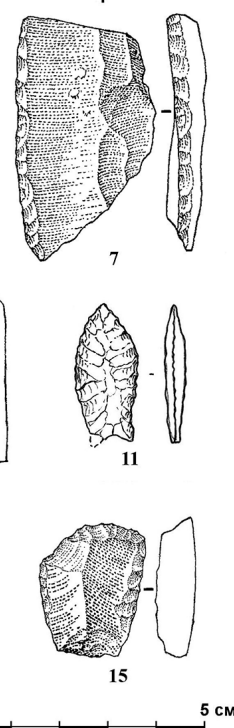

Fig. 7. Stone tools from the Oroshaemoe I settlement.
Povolzhie region is similar to the humid stage of the Middle Subboreal warming. The transgressive stage of the New-Caspian ba$\sin$ is registered about $7000 \mathrm{BC}$. The elevation of the water level in this period was 16-20m. Around 6600-6400 BC a short period of aridization occurred and cold climatic conditions were recorded. In this period the decreasing of broadleaf forest and the spreading of non-turfed areas has been found (Bolikhovskaya 2011). The climatic deterioration was also chronicled c. 6200$6000 \mathrm{BC}$ in the forest areas of the steppe zones of Eastern Europe (Spiridonova, Aleshinskaya 1999). After this event the climate became more favourable, but generally it was dry conditions.

According to the geochemical indicators, in the area of the Algay and Oroshaemoe sites the climate around $c .6000 \mathrm{cal} \mathrm{BC}$ was humid and warm. The anthropogenic impact on the Algay site was in this period low, in contrast to the Oroshemoe site where the first evidence of a people was found. Based on the archaeological data, in this period the carriers of the Orlovskaya Neolithic culture appeared in this region. The climatic 


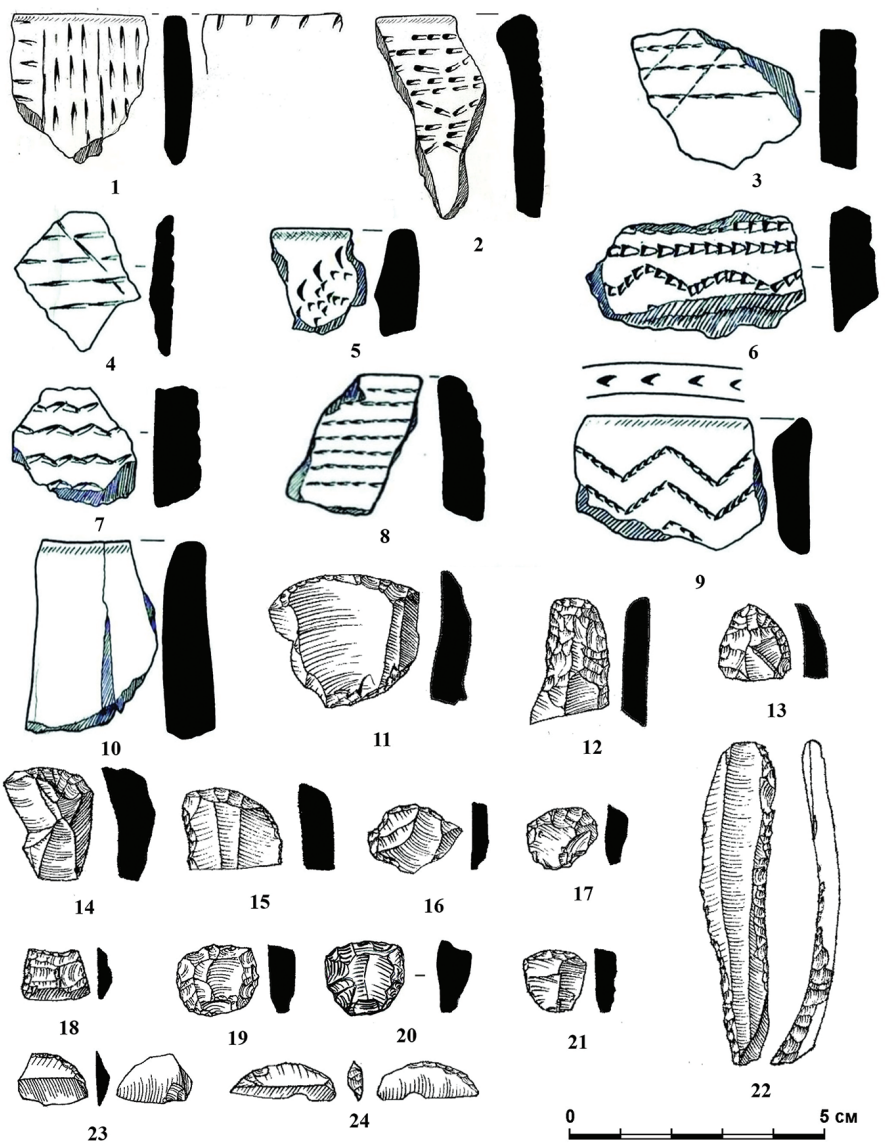

Fig. 8. Pottery and stone tools of the Orlovskaya culture from the Oroshaemoe I settlement.

conditions in this time were favourable. The period of $c$. 6400-5100 BC, according to pollen analysis provided by Bolikhovskaya (2011), is characterized as warm and moderately dry in the Low Volga region. At $c$. 6200-3580 BC the rate of alluvium accumulation in the floodplains of small rivers of the Kalachskaya hilltop decreased (Sicheva 1999). The regressive phase of the New-Caspian basin around c. 5900-5200 BC was at an altitude of $-28 \mathrm{~m}$. Open areas and a diversity of grass types and broad-leaved forests (linden, elm, beech, alder) were spreading. Cereals and grass prevailed. According to E. A. Spiridonova (1991), at 5500$5200 \mathrm{BC}$ in the northern part of the central part of Eastern Europe the forest area prevailed, and in the southern part the steppe zones were spreading.

At the Algay site, according to geochemical markers, the beginning of aridization appeared during $c$. 5656-5566 cal BC. Some increase in humidity is registered about 5350-5120 cal BC (Fig. 3). An increase in Algay site. anthropogenic activity was also noted in this period. The maximum of aridization was recorded in the deposits dated to 5050$4900 \mathrm{cal} \mathrm{BC}$ on the Algay site. These layers did not contain any cultural finds and the anthropogenic impact is low according to geochemical indicators.

According to Natalia P. Gerasimenko (1997), the climatic Holocene optimum in the steppe zone was registered during 5500-4500 BC. Bolikhovskaya (2011), on the other hand, suggests that the climatic optimum was 5100-4000 BC. The transgression in the New-Caspian basin increased to reach 18$28 \mathrm{~m}$ in $c .5060-3980 \mathrm{BC}$.

We register the transition to warm and humid conditions at $c$. 5060-4547 cal BC. These conditions probably correlate with the Holocene climatic maximum in the steppe zone. The high anthropogenic activity in the deposits corresponds to this time. The artefacts of the Cis-Caspian archaeological culture were found in this layer.

Strong aridization occurred around 4700$4500 \mathrm{cal} \mathrm{BC}$, based on the geochemical indicators. According to Bolikhovskaya (2011),

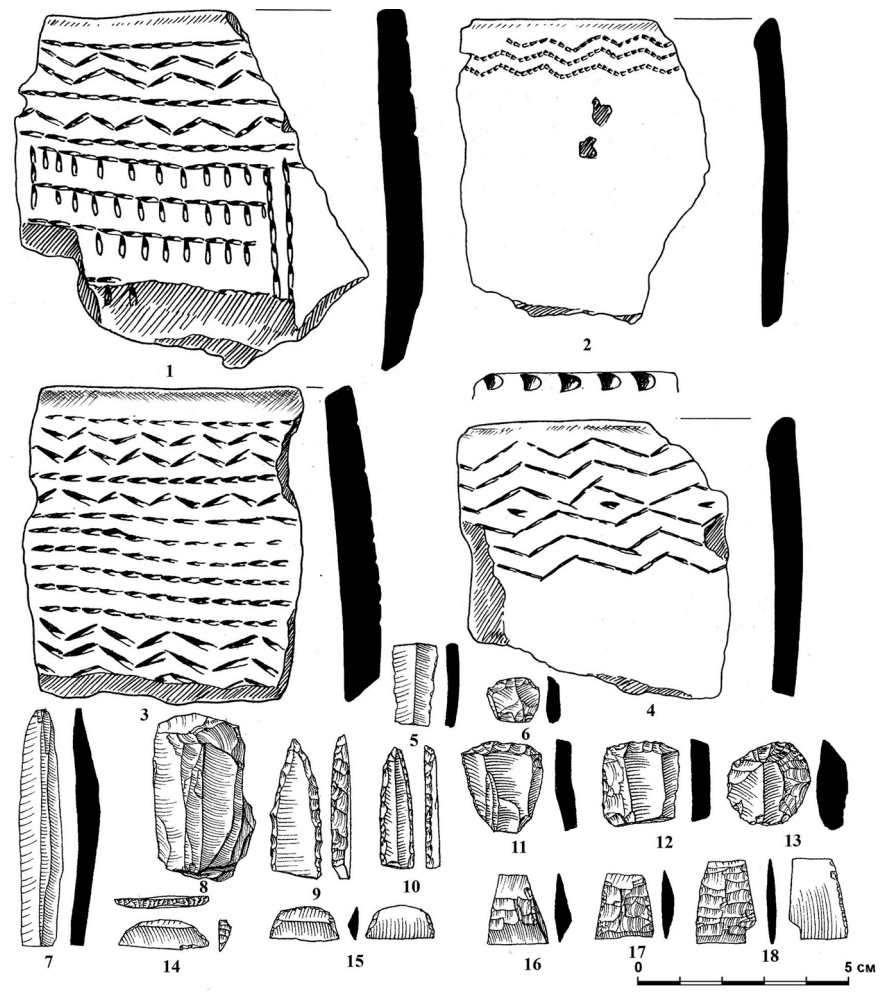

Fig. 9. Pottery and stone tools from the bottom layer of the 
the aridization of the steppe was registered at $c$. 4500$4400 \mathrm{BC}$, and this was the main factor in rapid decrease of the Caspian water level. After the climatic aridization at the Oroshaemoe site the transition to more favourable conditions resulted in the appearance of people from the Khvalynskaya Eneolithic culture at 4725-4336 cal BC.

\section{Conclusion}

The landscape-climatic conditions in the steppe area of
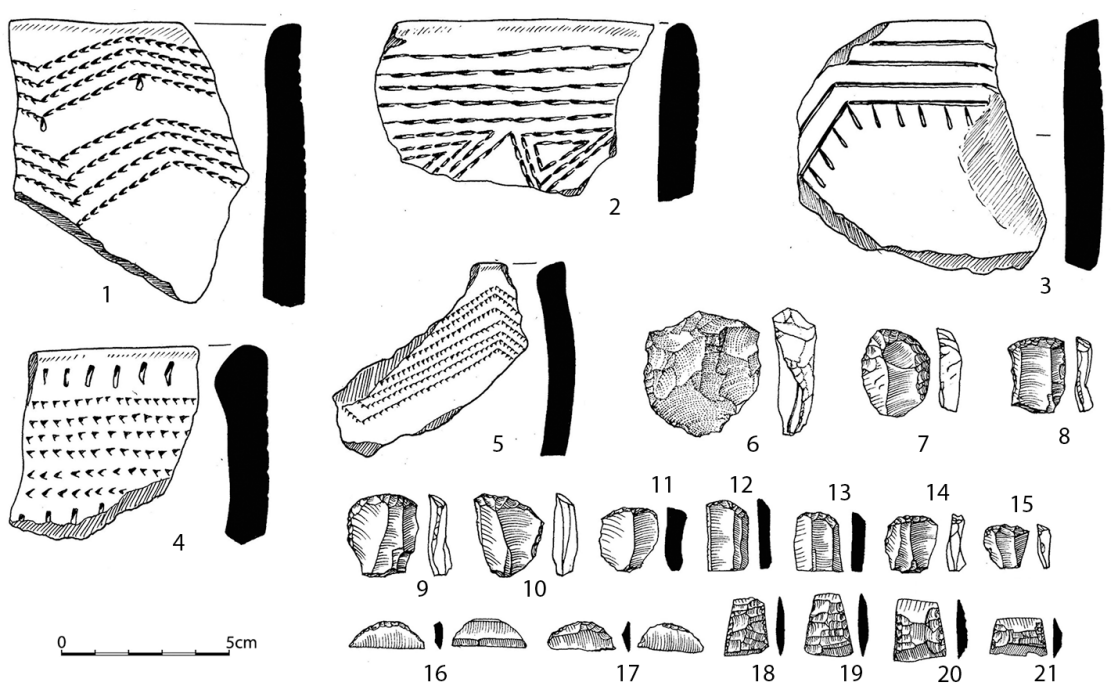

17

Fig. 10 Pottery and stone tools from the upper layer of the Algay site. the Lower Volga basin strongly impacted the development of ancient societies. In this paper we considered the adaptation of people in the past to environmental conditions in this region.

The first evidence of the Orlovskaya Neolithic culture is around $6200 \mathrm{cal} \mathrm{BC}$. In this period there was the transition to moderately humid and warm conditions that lasted till $c .6000 \mathrm{cal} \mathrm{BC}$. A sterile horizon without artefacts was sedimented at $c$. 6000-5900 cal $\mathrm{BC}$ in the period with the maximum of aridization.

The second stage of Orlovskaya culture development was registered at 5800-5500 cal BC on the Algay site. In this period the climate was humid and warm. The decrease in anthropogenic activity correlates with cold and dry conditions at 5660-5560 cal BC. In the later stage of the Orlovskaya culture (5300$5200 \mathrm{cal} \mathrm{BC}$ ) the climate was more humid and warm$\mathrm{er}$, and there were significant changes in the material culture of this stage. The influence of carriers with new cultural traditions in this period is probably reflected in these changes.
The next event of maximum aridization correlates with sterile horizons on both sites at $c$. 5100-4900 cal BC when the people abandoned this territory.

The new stage of anthropogenic activity is presented at Oroshaemoe the most clearly. This is the appearance of the Cis-Caspian culture (4900-4800 cal BC), the first with domestic animals.

The humid and warm conditions changed within a short period (around 100 years) due to aridization, and this caused the forming of a sterile layer. The development of the Khvalynskaya Eneolithic culture is dated to $4700-4400 \mathrm{cal} \mathrm{BC}$.

\section{ACKNOWLEDGEMENTS}

This article was prepared in the framework of the project 33.1907 of Government assignment of the Russian Federation Ministry of Education and Science and the RFFR project 18-09-00040.

\section{References}

Bolikhovskaya N. S. 2011. Evoluziya klimata I landshaftov Nizhnego Povolzhya v golozene. Vestnik Moskovskogo Universiteta. Seriya 5. Geografiya 2: 13-27. (in Russian)

Budja M. 2015. Archaeology and rapid climate changes from the collapse concept to a panarchy interpretative model. Documenta Praehistorica 42: 171-184.

https://doi.org/10.4312/dp.42.11
Bronk Ramsey C. 2009. Bayesian analysis of radiocarbon dates. Radiocarbon 51(1): 337-360. http://dx.doi.org/10.1017/S0033822200033865

Gerasimenko N. P. 1997. Environmental and climatic changes between 3 and $5 \mathrm{ka}$ BP in southern Ukraine. $3^{\text {th }}$ Millenium BC Clim. In H. N. Dalfes, G. Kukla, and H. Weiss (eds.), Third Millennium BC Climate Change and Old World Collapse. Nato ASI Subseries I, Vol. 49. SpringerVerlag. Berlin Heidelberg: 371-399. 
Kulkova M. A. 2007. Klimaticheskie katastrophy v rannem i srednem golozene I ih vliyanie na drevnie soobshestva. Radiouglerod $v$ archeologicheskih I paleoekologicheskih issledovaniyah. Institut Vysokomolekulyarnykh Soyedineniy Rossiyskoy akademii nauk. St. Petersburg: 316-333. (in Russian)

2012. Metodi prikladnih paleolandshaftnih geohimicheskih issledovanii. Herzen University Press. Saint-Petersburg: 152. (in Russian)

Nesbitt H. W., Young G. M. 1982. Early Proterozoic climates and plate motions inferred from major chemistry of lutites. Nature 299: 715-717.

Spiridonova E. A. 1991. Evoluziya rastitelnogo pokrova basseina Dona v verhnem Pleistozene-Golozene. Nauka Press. Moscow: 221. (in Russian)

Spiridonova E. A., Aleshinskaya A. S. 1999. Periodizaziya neolita-eneolita Evropeiskoy Rossii po dannim palinologichaskogo analiza. Rossiyskaya Arheologiya 1: 23-33. (in Russian)

Sicheva S. A. 1999. Ritmi pochvoobrazovaniya i osadkonakopleniya v golozene (svodka ${ }^{14} \mathrm{C}$ dannih). Pochvovedenie 6: 677-687. (in Russian)

Vybornov A. A. 2010. On the correlation of natural processes in the Neolitic Volgo-Kama. Documenta Praehistorica 37: 293-298. https://doi.org/10.4312/dp.37.25

Vybornov A., Kosintsev P., and Kulkova M. 2015a. The origin of farming in Lower Volga Region. Documenta Praehistorica 42: 67-75. https://doi.org/10.4312\dp.42.3

Vybornov A. A., Yudin A. I., Vasilieva I. N., Kosintsev P. A., Kulkova M. A., Goslar T., and Doga N. S. 2015b. Novie dannie po neolitu-eneolitu Nizhnego Povolzhya. Izvestiya Samarskogo nauchnogo zentra Rossiyskoy akademii nauk 17(3): 235-241. (in Russian)

Vybornov A. A., Oinonen M., Doga N. S., Kulkova M. A., and Popov A. S. 2016a. 0 khronologicheskom aspekte proishozhdeniya proizvodyshego hoziaystva v Nizhnem Povolzhie. Vestnik Volgogradskogo Universiteta. Seriya 4. Istoriya. Regionovedenie. Mezhdunarodnie otnosheniya 21 (3): 6-13. http://dx.doi.org/10.15688/jvolsu4.2016.3.1 (in Russian with English abstract)

Vybornov A. A., Yudin A. I., Vasilieva I. N., Kosintsev P. A., Kulkova M. A., Doga N. S., and Popov A. S. 2016b. Issle- dovaniya poseleniya Oroshaemoe v Nizhnem Povolzhie. Izvestiya Samarskogo nauchnogo zentra Rossiyskoy akademii nauk 18(3): 140-145. (in Russian)

Vybornov A., Kulkova M., Andreev K., and Nesterov E. 2017a. Radiocarbon chronology of the Neolithic in the Povolzhie (Eastern Europe). Documenta Praehistorica 44: 224-239. https://doi.org/10.4312/dp.44.14

Vybornov A. A., Yudin A. I., Vasilieva I. N., Kosintsev P. A., Kulkova M. A., Doga N. S., and Popov A. S. 2017b. Novie materiali issledovanii na poselenii Oroshaemoe v Nizhnem Povolzhie. Izvestiya Samarskogo nauchnogo zentra Rossiiskoi akademii nauk 19 (3): 185-190. (in Russian)

Vybornov A., Kulkova M., Kosintsev P., Platonov V., Phillipsen B., and Nesterova L. A. 2018a. Diet and Chronology of Neolithic-Eneolithic Cultures (From 6500 to $4700 \mathrm{Cal}$ BC) in the Low Volga Basin. Radiocarbon 60: 1597-1610. https://doi.org/10.1017/RDC.2018.95

Vybornov A. A., Vasilieva I. N., Kulkova M. A., and Phillipsen B. 2018b. 0 vremeni poyavleniya i dinamike rasprostraneniya drevneishih keramicheskih tradizii v stepnom Nizhnem Povolzhie. Vestnik Volgogradskogo Universiteta. Seriya 4. Istoriya. Regionovedenie. Mezhdunarodnie otnosheniya 23(2): 6-16.

https://doi.org/10.15688/jvolsu4.2018.2.1

Vybornov A. A., Yudin A. I., Vasilieva I. N., Kosintsev P. A., Doga N. S., Popov A. S. Platonov V. I., and Roslyakova N. V. 2018c. Novie resultati issledovanii na poselenii Oroshaemoe v Nizhnem Povolzhie. Izvestiya Samarskogo nauchnogo zentra Rossiyskoy akademii nauk 20(3): 215-222. (in Russian)

Yudin A. I. 2004. Varfolomeevskaya stoyanka $i$ neolit stepnogo Povolzhya. Saratov State University Press. Saratov. (in Russian)

2012. Stoyanka Kumiska i eneolit stepnogo Povolzya. Saratov State University Press. Saratov. (in Russian)

Yudin A. I., Vybornov A. A., Vasilieva I. N., Kosintsev P. A., Kulkova M. A., Goslar T., Philippsen B., and Baratskov A. V. 2016. Neoliticheskaya stoyanka Algay v Nizhnem Povolzhie. Samarsky nauchnii vestnik 3(16): 61-68. (in Russian)

Yudovich Ya. E., Kertis M. P. 2000. Osnovi litogeohimii. Nauka Press. Moscow. (in Russian)

\section{back to contents}

